\title{
STEAM approach in architectural education
}

\author{
Elif Süyük Makakl1 ${ }^{*}$ \\ ${ }^{1}$ Işık University, Architecture and Design Faculty, Architecture Department, İstanbul,Turkey
}

\begin{abstract}
Architecture practice is reshaped by new technological developments such as virtual reality, augmented reality, 3D printing, computational design, robotics, etc. Future architects are expected to deliver spatial solutions, to understand changing living conditions and to discover the different future by responsing technological improvements. In architecture schools, students should explore and investigate design practice with different production methods, systems and materials by using various technologies in collaborations with interdisciplinary partners and industry. The study aims to understand the STEAM concept which is considered as a promising education approach and formulated; science, technology, engineering, math and then adds an 'A' for arts which represents the creative thinking and design approach. The STEAM concept and its place in the architectural education are discussed. The discipline of architecture is an intersection of technology, art and science. The architecture schools' curriculum reflects the interdisciplinary STEAM nature throughout the history. Virtual Reality (VR) is created through interdisciplinary technology and has the potential to prepare the students to future, to develop analytical and abstraction abilities.
\end{abstract}

\section{STEM to STEAM}

STEM (formulated; science, technology, engineering, math education) has emerged as a reform movement impacting science education in 1990s in the USA and then received attention on a global scale. The aim is to make innovations by STEM related skills to translate scientific ideas into practical technologies which have socio-economic impacts. An integrated STEM education approach is defined by Moore et al. As: "an effort to combine some or all of the four disciplines of science, technology, engineering, and mathematics into one class, unit, or lesson that is based on connections between the subjects and real-world problems"[1]. It is generally used to imply innovative approach of even disconnected subjects [2,3]. The four letter acronym STEM broadened to STEAM by adding an ' $A$ ' for arts which represents the creative thinking and design approach. The main aim is to provide a well-rounded approach to education [4]. It is examined in a variety of settings, from elementary and middle schools to higher education.

\footnotetext{
* Corresponding author: elif.suyuk@isikun.edu.tr
} 


\section{STEAM in architectural education}

The world of today faces major problems and their solution requires interdisciplinary approaches and collaboration of different disciplines. The interdisciplinarity is defined by Director-General of Unesco in 1985 as;

'In epistemological terms, the concept of interdisciplinarity may be regarded as a form of co-operation between various disciplines, which contribute to the achievement of a common end and which, through their association, further the emergence and advancement of new knowledge'.[5]

STEAM represents an interdisciplinary learning approach that is more creative and problem- or project-based in nature. Hobs defined world's innovative people as early practitioners of the STEAM concept and mentioned Leonardo Da Vinci who combined mathematics and art to explore the theories of the Roman architect Vitruvius on the proportions of man in the 'Vitruvian Man' [6].

Architectural education has already a history with the interdisciplinary thinking that STEAM represents. From the antiquity perspective of Vitruvius, the discipline of architecture should include other disciplines from both the sciences and arts. He described in The Ten Books of Architecture the education of an architect:

"The architect should be equipped with knowledge of many branches of study and varied kinds of learning, for it is by his judgment that all work done by the other arts is put to test."

"Since this study is so vast in extent, embellished and enriched as it is with many different kinds of learning, I think that men have no right to profess themselves architects hastily, without having climbed from boyhood the steps of these studies and thus, nursed by the knowledge of many arts and sciences, having reached the heights of the holy ground of architecture" [7].

The interdisciplinary context is realised in architectural studio which emerged as an exclusive form of education within the Ecole des Beaux Arts and the significance of design practice for architectural education remained present. Throughout history transformative events affected architectural pedagogy like in any other discipline however the Design studio is the most important space for the education of architecture and the core of its architectural pedagogy. Studios have been the field application of STEAM in design.

Walter Gropius established the Bauhaus in Weimar in 1919 as a teaching institution whose core was design. The aim was to unify art, science, and technology under a new pedagogy which reflects professional practice.

The school should be absorbed into the studio and that the manner of teaching should arise from its character, that is, the studio should not be an adjunct of the other teaching programmes. On the contrary, all the teaching programmes should exist only to support the studio and the design problems it is working on, reflecting the reality of professional practice, which is entirely driven by the needs of the project [8].

The mission of architecture is to create human environments, not only physical but also social and psychological. The discipline engages with the world - urban, spatial, visual, and social issues as well. Critical problems related to architecture can be stated as; ecological concerns, providing shelter for the displaced, the use of material and its corresponding energy. Simulation tools are used to evaluate different kinds of building performances, such as testing structural, energy-related, and acoustics performances. Improving the sustainability of the built environment is an essential and this will demand creativity and joint working. Architecture is in fact inherently interdisciplinary already, as the process of building requires various inputs from different disciplines.

Creative activity is one of the most significant parts of architectural education. One of the main objectives of Architecture Schools is to stimulate artistic sensitivity and creative 
powers. The integration of architectural ideas takes place in design, through experimentation, critique and debate. Design education is an intersection of technology, art and science, and design schools' curriculum reflects this multidisciplinary nature. Three basic aspects of design education is defined by Ledewitz, [9] as; learning and practising a number of new skills, such as visualization and representation, learning a new language and learning to think architecturally. The typical architecture curriculum includes design studio as the core subject, the teaching occurs in the studio and the other essential skills are design theory, history, visual communication and representation, building technology, etc. In addition to lectures teaching formats include seminars, workshops and researches which contribute to education. According to the boards that assess the quality of architecture education in universities, (NAAB 'National Architectural Accrediting Board in the U.S.A' and RIBA 'Royal Institute of British Architects in the UK') the core subjects of education, design, humanities (history and culture), building technology, (including environment and structures), and professional studies.

\section{VR Technology}

Space has been described in different ways with the opportunities technology enabled after 20th century. Architectural design and production and how we relate to the world is changing and transforming by the advances in digital technologies such as virtual and augmented reality. The future of architectural education will be different than we now think and new ways of describing what an architect needs to know may engender new learning environments. The virtual space design opens a new discovery area to question the space, and fosters a new understanding/experience of space. The boundaries between the virtual and the physical, and understanding of fictional and real and the impact of virtual tools on the architectural practice are questioning. Imaginative possibilities for architecture are broadening with these new technologies. Virtual Reality (VR) technology is highly interdisciplinary technology which includes computer technology, human computer interactive technology, and measuring and control technology. The 3D virtual environments have the potential to provide a rich, interactive, engaging educational context, supporting experimental learning [10]. Pantelidis mentioned the key potential role of virtual reality to be used to teach a subject[11].

In the historical process, usage of virtual reality started in defense industry at the end of 1920s when aeroplane designers started working on flight simulators in order to improve flight experience. A stereoscopic television 'Sensoroma' which is a multi-experience visualisation system was made that adresses a lot of senses in 1956. In 1980s, Jim Clark from Stanford University put changing graphics into pilots' helmets as 'super cockpit' which changes when they look into different directions. In 1980s, first virtual reality glove was produced in VPL Research company. After 1989, Autodesk presented the first PC based virtual reality system in Fake Space Labs. In 1990s, desktop virtual reality spaces were moved visually with a computer interface which is not spiral [12].

In spiral virtual reality, display systems (virtual reality glasses, monoscopic screen), sound systems (earphones, speakers), movement tracking systems (kinetic camera, inertial movement unit, gyroscope, GPS) tactile feedback systems (tactile remote controls) are used as components of the creation[13].

Three basic characteristics of VR can be defined as; immersion, interaction and imagination. Heim describes virtual reality with concepts of density of information, interactivity, and immersion [14]. Pimentel and Texiera describes features of virtual reality as reacting to user's movements, producing three dimension real-time graphics and creating immersion feeling [15]. These spaces are created with computer support and can be 
experienced with the help of different electronic tools. Physical and artificial interactions of the space are being questioned with the improvement of virtual space concept and mass communication tools. New representation environments present new evolutions in improving spatial ideas, evaluating and interpreting them. Machine, human, space and future relations are studied in interdisciplinary environment by different disciplines and the variety and opportunities different designs are presenting have a place in architecture. Real space represents space where one can perceive physically, can designate the limits, is in physically, and which can be measured geometrically; virtual space is in an independent structure from physical world. A new reality can be created by fictionalising virtual space as a replica of the reality by copying the physical world and also by designing a new space by using physical world as base and having its own features.

Virtual reality technology which is one of the layers of these experiences changes and influences our time, dimension and architecture perceptions by taking us into a different universe than physical space that is experienced spiritually and mentally in new space creations. There is a different depiction of the reality in this universe and provides a new universe experience by being nourished by technology in sensorial wise.

\section{VR Technology in architectural education}

The position of virtual reality in architectural education becomes more apparent. 3D perception of students would be enhanced by implementation VR in architectural pedagogy and also conceptual and spatial experiments with architecture and design. Michael Heim (1994) describes VR as 'a technology that can be applied to every human activity and can be used to mediate in every human transaction'.

Designing VR environments needed interdisciplinary expertise and also the contribution of architectural thinking to increase its spatial experience. How the VR reconfigure architectural design and production is an interesting research area for the architecture schools. They are experimenting spaces that explore new horizons for architecture. The implementation of VR in architectural pedagogy is structured in different ways in different concepts. In the selected 3 cases the VR technology is used in different types of teaching/experimenting with different concepts and duration, the course/project/experiment descriptions are taken from the websites of the universities or related publications.

\section{Case 1 Virtual Design Studio conducted as Workshop}

MIT/Virtual Experience Design Lab- Virtual Design Studio By Eytan Mann \& Cagri Zaman

'How to use immersive technology to imagine the future of design education was questioned at The Design Studio 2.0 workshop which explored novel sensory and material experiences enabled by virtual reality. The aim of the workshop was defined as developing formal design methods that were informed by sensory experiences and bodily interactions within immersive digital environments. Design framework included photorealistic immersive visualizations, digital lighting and material design, and spatial sound design. Students imagined and created novel architectural experiences and narratives using cuttingedge virtual reality tools. The virtual design studio took five days in three weeks and students who attended took 3 credits. Students prepared 3D models and exported them to virtual reality engine by emphasizing photorealistic material preparation and lighting for architectural models [16]. (Figure 1) 

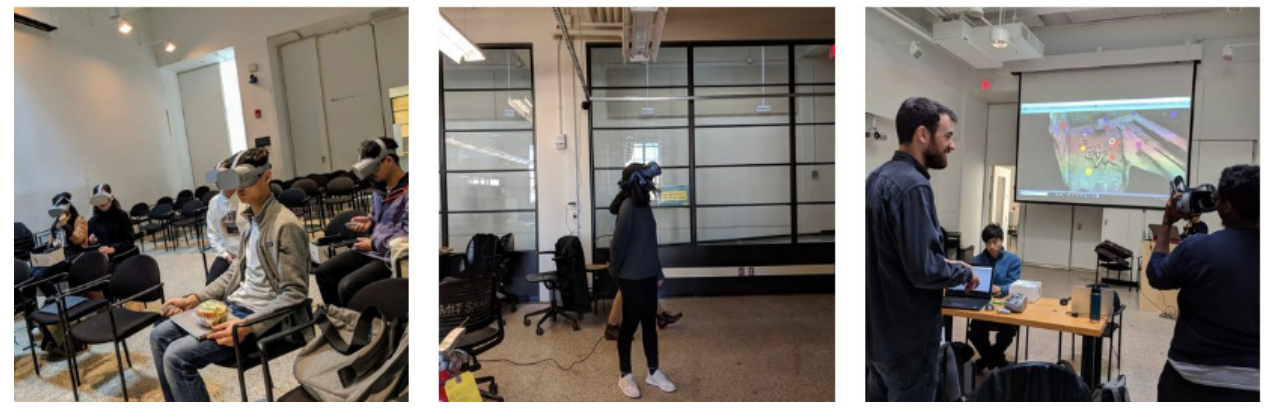

Fig. 1. Virtual Design Studio By Eytan Mann \& Cagri Zaman.

https://www.cagrizaman.com/projects/nb2xh86bghegja4864c35w5awdr3wb

Two days in the second week called as VR Design Challenge which was organized as a design hackathon. Students who worked in small groups to iterate over an existing architectural design of their choosing and explored how perceptual, sensory and material qualities inform design process and become integral parts of architectural representations in virtual reality. The design hackathon run 8 hours/ day. In the third week they were asked to present their work[16].

\section{Case 2: Visualising Virtual Spaces-Course, (The University of New South Wales UNSW Sydney}

Spatial Design: 'Visualising Virtual Spaces course is intended to develop the skills in the design and visualisation of virtual spaces. The aim is on their applications in the fields of urban and landscape design, architecture, interior design, and heritage studies. Students should explore the possibilities of virtual space and reconstruct and reconfigure virtual heritage environments and also design the kinds of fantasy spaces that can only exist in the digital realm. Students will develop skills in the design of virtual 3D models and learn to produce fly throughs and photorealistic visualisations using programs such as Vectorworks, Photoshop, and associated rendering software. Assessment is based on demonstrated ability to design virtual spaces and produce $2 \mathrm{D}$ representations. The course can be taken as spatial design studio stream or as an elective course[17].'

\section{Case 3: CAP VR Environment-Experiment-College of Architecture and Planning (CAP) at Ball State University}

The CAP VR Environment has been used as a tool for simulating and testing the effectiveness of architectural spatial experiences. Experiments were conducted with the involvement of undergraduate and graduate students of Architecture by using the CAP VR Environment, which is a fully implemented VR environment equipped with a tracking and a Head Mounted-Display (HMD) system [18].

CAP VR Environment is used in design studios for simulating and testing the effectiveness of architectural spatial experiences and contributed to develop teaching/learning methodologies for effectively using immersive VR environment. 


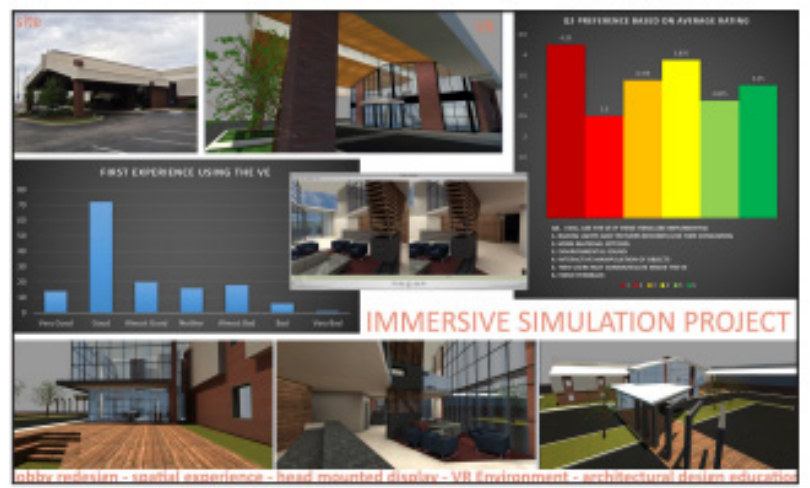

Fig. 2. The Immersive Simulation of Spatial Experiences, Project By Antonieta Angulo [16].

\section{Conclusion}

STEAM represents an interdisciplinary learning approach that is more creative and problem- or project-based in nature. Architectural education has a history with the interdisciplinary thinking that STEAM represents. The design of the space, which constitutes the essence of the profession of architecture, is structured in architecture schools with an interdisciplinary curriculum. In architectural education offered courses should reflect contemporary and emerging issues in architecture.

Among the others, VR technology has the potential to improve architectural students' learning capacity. How to educate future architects to solve the problems of tomorrow with the tools of today is one of the key questions of the schools. In addition the skills needed to understand physical space, material and volume, also skills needed to understand virtual space find its place in the content of architectural education. In a rapidly changing world architecture schools are exploring new ways of thinking about architecture, education, and design through research. The basic aim of architecture schools is broadening students' understanding and problem solving capacity. Architecture schools set their own curricula and the way of teaching. VR technology and its contributions to design education is realized and being used with various settings and tools with different aims. VR technologies should be included not as a tool but also as a platform to open new experiences of space and space design as it encompasses a new space concept, and a new learning area. It has been observed that VR technologies can be integrated into the architectural education by constructing them differently, and they can provide learning opportunities in different dimensions. The selected 3 cases structured differently and considered as positive as they have the potential to open new dimensions and layers to understand the space concept by the students. The learning outcomes should be further evaluated and new formats of teaching and learning methods should be created by different stakeholders.

The concept of virtual space, which brings new expansions to space perception and presents new dimensions in space design, is considered to be an important element for architectural education with its STEAM approach and interdisciplinary dimensions. VR environments present new evolutions in improving spatial ideas, evaluating and interpreting them. In architecture schools, students should explore and investigate design practice with different production methods, systems and materials by using various technologies in collaborations with interdisciplinary partners and industry. As part of design education, how virtual spaces integrated to education how it will be designed in the future, how it will be used and the suitability to design principles should be further evaluated. 


\section{References}

1. Moore, T., Stohlmann, M., Wang, H., Tank, K., Glancy, A., \& Roehrig, G. (2014). Implementation and integration of engineering in K-12 STEM education. In S. Purzer, J. Strobel, \& M. Cardella (Eds.), Engineering in Pre-College Settings: Synthesizing Research, Policy, and Practices (pp. 35-60). West Lafayette: Purdue University Press (2014).

2. Sanders, M., STEM, STEM education, STEMmania. The Technology Teacher, 68(4), 20-26, (2009).

3. Wang, H., Moore, T. J., Roehrig, G. H., \& Park, M. S., STEM integration: teacher perceptions and practice. Journal of Pre-College Engineering Education Research, 1(2), 1-13. doi:10.5703/1288284314636, (2011).

4. Rolling Jr., J. H., Reinventing the STEAM engine for art+design education. Art Education, 69(4), 4-7, (2016).

5. Interdisciplinarity in General Education, A study by Louis d'Hainaut following an International Symposium on Interdisciplinarity in General Education held at Unesco Headquarters from 1 to 5 July 1985, http://www.unesco.org/education/pdf/31_14.pdf

6. Hobbs, L., 2019 Powering the Digital Revolution, p.237-249, The STEAM Revolution, Transdisciplinary Approaches to Science, Technology, Engineering, Arts, Humanities and Mathematics: Springer, (2019).

7. Morgan, M., Vitruvius: The ten books on architecture. New York: Dover Publications, (1960)

8. Gropius, W., The Bauhaus. Architectural Educ., 1 (1983).

9. Ledewitz, S., 'Models of design in studio teaching', Journal of Architectural Education, 38(2), pp 2-8, (1985).

10. Mantovani, F., VR learning: Potential and challenges for the use of $3 \mathrm{D}$ environments in education and training. In Riva, G. \& Galimberti, C. (Eds.). Towards cyber psychology: Mind cognition and society in the internet age. Amsterdam: IOS Press. pp. 207-225.), (2003).

11. Pantelidis, V. S., Virtual reality in the engineering classroom. Computer Applications in Engineering Education, 5 (1), 3-12, (1997)

12. Karışma A., İnternet Ortamında Sanal Gerçeklik Kullanım Örnekleri.YüksekLisans Tezi. Mimarlık Anabilim Dalı Gazi Üniversitesi Fen Bilimleri Enstitüsü, (2017).

13. Kılıç T.,Sanal Gerçeklik Teknolojisinin Mekânsal Deneyim Odaklı Kullanımı Üzerine Bir İnceleme. Mimar Sinan Güzel Sanatlar Üniversitesi.İstanbul: MimarlıkFakültesi, İç Mimarlık Bölümü, (2016).

14. Heim, M., 1998. Virtual Realism, Oxford University Press, New York Oxford, (1998).

15. Pimentel, K.,Texiera, K., 1995. Virtual Reality: Through The New Looking Glass, New York : Intel/McGraw-Hill, (1995).

16. https://architecture.mit.edu/sites/architecture.mit.edu/files/attachments/course/180904 MITArch150_Experiments-Final-Print.pdf

17. https://www.handbook.unsw.edu.au/undergraduate/courses/2019/SDES3412

18. Angulo, A., Rediscovering Virtual Reality in the Education of Architectural Design: The Immersive Simulation of Spatial Experiences, Ball State University, College Of Architecture and Planning, Faculty \& Student Symposium, (2014) 